Portland State University

PDXScholar

$11-15-2018$

\title{
"I Do Not Speak French": Cruising, Magic, and Proust's Queer Sociability
}

Finn Turner

Portland State University

Follow this and additional works at: https://pdxscholar.library.pdx.edu/honorstheses

Let us know how access to this document benefits you.

Recommended Citation

Turner, Finn, "'I Do Not Speak French": Cruising, Magic, and Proust's Queer Sociability" (2018). University Honors Theses. Paper 642.

https://doi.org/10.15760/honors.657

This Thesis is brought to you for free and open access. It has been accepted for inclusion in University Honors Theses by an authorized administrator of PDXScholar. Please contact us if we can make this document more accessible: pdxscholar@pdx.edu. 
"I Do Not Speak French": Cruising, Magic, and Proust's Queer Sociability

by

Finn S. Turner

An undergraduate thesis submitted in partial fulfillment of the requirements for the degree of

Bachelor of Arts

in

University Honors

and

French

Thesis Advisor

Carrie Collenberg-Gonzalez

Portland State University

2018 


\section{CONTENTS}

Introduction 2

“I Do Not Speak French”: Conventions of Cruising in Proust's Paris 8

Between Men: Sexuality on the Threshold 23

"Queer Little Gods": On the Spirit of Cruising 31

The Discreet Charm of the Aristocracy: Sex, Class, and Fetishism 44

Conclusion $\quad 5^{6}$

$\begin{array}{ll}\text { Works Cited } & 61\end{array}$ 


\section{INTRODUCTION}

"I do not speak French," says the duc de Châtellrault to his older companion as they walk down the Avenue Gabriel. This is, of course, a lie. Yet to identify himself as a Frenchman, and much less a member of the nobility, would be rash. To the stranger beside him he is an Englishman, a stranger in Paris himself. So they go on walking, the duke feigning incomprehension as the other man repeatedly asks his name, so desirous to see such a generous lover again. What neither knows is that they will encounter each other only days later, under less than ideal circumstances: the older man, a domestic servant of an aristocratic family, will be announcing the guests at a soirée to which the duke is invited. The older man will get his wish: to know the stranger's name. The duke, on the other hand, will be terrified that the other guests will find out what occurred between the two, precipitating his wholesale social exile.

The above roughly summarizes one of several cruising encounters that takes place in Marcel Proust's À la recherche du temps perdu (published in seven volumes between 1913 and 1927). It is a brief passage, occupying around a page of the novel's approximately 3,000, yet for this reader, it is precisely its brevity and apparent insignificance that marks it as fertile ground for analysis. In fact, its presence in the novel is itself bizarre given that Proust goes well out of his way to narrate the duke and usher's meeting, an event which his first-person narrator could not possibly have observed. Michael Lucey's reading of this unconventional narrative contortion was a catalyst for my own project (see Lucey 241-249), and while I incorporate his arguments, my reading takes a different approach. If Proust took care to work the passage into the novel at the risk of undercutting the 
pretenses of its first-person narration, its subject matter—not only homosexuality, but queer sex in public spaces—must have been significant.

The meeting described in this passage is transgressive, but not unusual. Paris during Proust's lifetime (1871-1922) was thriving with public sex, gay and straight. Its public sexual culture would reach its apogee during the 20 s and 30 , though it would virtually disappear during World War II and never rebound during in the post-war era. Proust was not ignorant of the prevalence of public sex, nor of sex's entangment with other social issues of Third Republic Paris (1870-1940). His father, the renowned physician Adrien Proust, was an avid promoter of personal hygiene and public sanitation. Among his many publications was L'hygiène du neurasthénique (written in conjunction with Gilbert Ballet and translated into English as The Treatment of Neurasthenia), a treatise that linked the ill-defined condition from which his son suffered with, among other things, excessive masturbation (Finn 285). Although Dr. Proust's attitude towards his son's illness and objections to his masturbatory habits were points of contention in their often antagonistic relationship, Proust's quasi-medical analyses of homosexuality bear the mark of his father's influence (Carter 8). While it is not necessarily clear whether the novelist himself engaged in public sex, he was a frequent guest at the male brothel of his friend Albert Le Cuziat on the rue de l'Arcade, and was arrested during a raid there in January 1918 (143). The verisimilitude of his portrayals of cruising encounters suggests not only a familiarity with the practice, but also an understanding of its crucial role in facilitating same-sex sexual intimacy. In fact, there is hardly a single depiction of queer sexuality in the Recherche that is confined neatly to the bedroom. 
This paper does not posit cruising as a key to Proust's novel any more than it argues for Proust's writing as a tool to theorize cruising. Instead, it works to contextualize sexuality within the Recherche, exploring its entanglement with the novel's more famous themes (time, memory, society, etc.). In brief, my critical project is to situate queer desire, and cruising as an expression of it, within the thematic web of the novel, such that it can be studied not as a single, isolable theme, but as part of an elaborate textual conversation within Proust's cuvre. Far from presenting cruising as a keystone to the novel, I read the Recherche as nothing but keystones, with each theme both informing and complicating the others. Furthermore, I argue that cruising plays a redemptive role in Proust's social vision, while refraining from an uncritical utopian reading that would be at odds with textual evidence.

By way of introduction, I present a kind of anatomy of cruising as it was practiced in Proust's Paris, roughly between the 1870 s and 1920s. Here I compare the encounter between the duc de Châtellrault and the Guermantes' usher with information gleaned from primary sources from the Third Republic as well as historical studies of the era's sexual subculture in order to limn its conventions. Following this study, my analysis of Proust's text is tripartite. First, I examine the spaces of cruising in the novel, specifically the park in which the duke and usher cruise one another, and the threshold of the soirée where they meet later on. Queer desire in the Recherche, I argue, is often defined by anxiety over boundaries, especially those between public and private space such as the Guermantes' threshold — an anxiety that may be relieved in encounters that do not require one to cross a physical boundary. In response to the problems posed by boundaries, I propose that the spiritual world of the Recherche, animated by guardian spirits and shaped by Neoplatonic principles, 
can offer a useful model for understanding the singular role that cruising plays in the text.

Furthermore, I argue that queer desire is animated by this divinity-field as much as Proust's more famous themes, e.g. time, memory, etc. Finally, I attend to the class dynamics between the duke and usher and question whether or not their cross-class intimacy belies a utopian impulse.

I contextualize Proust in relation both to the author's philosophical parentage and to the theories of public sex that have emerged in the last two decades. Neoplatonic thought in particular had a marked influence on his writing, especially as it was transferred to him by contemporaries such as Ralph Waldo Emerson and Henri Bergson. The Neoplatonic worldview permeates the Proustian universe, informing the social meanings and emancipatory potential of cruising in the novel. Proust's synthesis of these influences in turn prefigures the work of scholars such as Samuel Delany, José Esteban Muñoz, Tim Dean, and Sarah Ensor. In various ways, these writers have argued for cruising as an ethical model for negotiating otherness, whether between urban strangers, different economic classes, or even humans and the environment. Cruising in Proust, inflected with mysticism and governed by minor deities, nonetheless shares with these scholars a redemptive understanding of cruising as social, spatial, and embodied practice.

I consider my method to be close reading, however in addition to analysis on the lexical and syntactical level, I also move liberally within the text of the novel and even outside of it. With the episode of the duke and usher as an anchor and interpretive key, I map how this passage points to broader themes and currents in the Recherche, and explore the significance of these linkages. At one point, this method of reading leads me away from the Recherche and into Proust's earlier writings. This departure from the text is justifiable if, like most scholars of Proust, I read Les Plaisirs et les jours, Jean 
Santeuil, and other earlier texts as both independent works and as a kind of prewriting for the Recherche. Moreover, such an excursion is consistent with my general project of mapping the pervasiveness of queer desire in Proust's work.

I approached this project with more hopes than I did expectations. My guiding precept was to follow the text, allowing the act of reading to furnish the material and structure of my writing, without enforcing an outline or hypothesis that could restrict my reading and preclude surprises. The structure of this thesis reflects, for better or worse, my strategy of reading, with its twists and turns following those I experienced while writing. The result is an essayistic form that departs from and returns to the chosen passage, applying a series of lenses to it. Finally, my thesis is an expression of the time spent writing and researching, of the conversations, frustrations, and discoveries that shaped it. In this way, I feel that it is animated by the spirit of Proust's novel, the organic growth of which, as early detractors argued, engendered unnecessary diversions that some compared to cancerous tumors. While I consider neither my thesis nor Proust's novel to be cancerous, I do hope that I have preserved for readers, in whatever diminished form, the natural contours of my reading and the unexpected surprises that, like the sudden recognition of a cruiser's inviting gaze, determined my course more than I could have ever foreseen.

I should also note that I use many anachronistic terms here for the sake of linguistic convenience. In fin de siècle France, little of our contemporary language around sex and sexuality existed, and what did was often euphemistic. For example, though cruising is at the center of my project, neither the English word nor its French equivalent, la drague, were current at the time. La drague, furthermore, refers also to flirtation and the pursuit of partners in general and, unlike cruising, 
does not have a specifically gay connotation. As Daniel Guérin remembered of the 1920s, "on n'employait guère à l'époque ce mot-là [la drague]. On disait « aller avec quelqu'un "” [that word was barely used at the time. We said "going with someone"] (Barbedette \& Carassou 53, my translation). Cruising, however, is an effective shorthand for the varieties of public and semi-public sexual intimacies I discuss, even if the term generally refers to the search therefor. I also use "queer," "homosexual," and "gay" frequently, though these terms have little rapport with sexuality at the time of Proust's writing. In fact, I consider my use of these terms to be a kind of betrayal, since it was the very absence of such categories that helped to facilitate the fin de siecle Paris' remarkable sexual permissiveness. However, as Proust himself made linguistic concessions in describing sexualities that resisted definition, I in turn wrestle with the language of sexuality's limitations in order to do justice, both to Proust's text, and to the queerness of the past.

Finally, though I appreciate the work that queer has done in this regard, I am also cautious of using it as a catch-all for non-normative behavior, especially since this thesis deals overwhelmingly with what we would now understand as cisgender men. Despite the threats posed to these Parisians by the forces of order, it is certain that men who presented as such could trawl the dark corners of the city with minimal threat to their safety. In many ways cruising was and is a male phenomenon, and any argument for its emancipatory, even utopian potential, must account for this lacuna. Unfortunately, given the constraints of this project, I am unable to address these problems in detail, and must make the best use possible of the language I have at my disposal. In my future research I hope to give more space to exactly how sexuality is constructed in Proust, and how Proustian sexuality relates to the 
medical and criminal understandings of it that circulated at the time. For the moment, however, let us rest uneasily with the inadequacy of language, French or English, to express desire.

While I frequently refer to $\grave{A}$ la recherche du temps perdu (or simply the Recherche) as a whole work, the passage that is the focus of this study is found in the early pages of Sodome et Gomorrhe (1921-22), the novel's fourth volume. Of the other volumes, I refer primarily to Du côté de chez Swann (1913), À l'ombre de jeunes filles en fleurs (1919), La Prisonnière (1923), and Le Temps retrouvé (1927). I provide translations of all French text, with citations for the original first, and the English second. For this paper, I cite the authoritative French edition of the Recherche published by the Bibliothèque de la Pléiade in four volumes $(1987-89)$, as well as the Modern Library edition translated by C.K.

Scott Moncrieff and Terence Kilmartin and revised by D.J. Enright (2003). For Les Plaisirs et les jours, Proust's first collection of short stories and prose poems, I use the Pléiade edition which also contains Jean Santeuil (1971), as well as the Hesperus translation by Andrew Brown (2004).

\section{“I Do Not SPEAK French": The CONVENTIONS OF CRUISING In ProusT’S PARIS}

Cruising, though at least as old as the city itself, has been subject to academic inquiry for a remarkably short time, with the first book-length studies appearing in the early 199os. Lauren Berlant and Michael Warner's "Sex In Public” (1998) and Samuel Delany's Times Square Red, Times Square Blue (1999) are generally regarded as seminal texts on the topic, followed by Leo Bersani's 
“Sociability and Cruising” (2002) and José Esteban Muñoz’ Cruising Utopia (2009), among others. In the last decade, scholars like Tim Dean and Sarah Ensor have taken psychoanalytic and ecological approaches, respectively, to the study of cruising. What these theorists share, to varying degrees, is a belief that cruising is in some ways ethically exemplary—not that it is congruent with normative ethics, but that it allows for the articulation of a new ethical vocabulary concerning questions of public and private life, of identity and otherness, of risk and care, and of intimacy in spite of (even on the basis of) strangeness and transience.

For some, like Delany and Bersani, the ethical dimension of anonymous sex is implicit in the particular kind of socialization it entails, divorced from the network of specific social relations. Essential to the "pure relationality" of cruising is a relief from identity and its exigencies, a state of what Bersani calls "self-subtracted being," that attends varieties of socialization that are not acquisitive or self-interested (10-11). Others, Dean and Muñoz among them, build on this mode of pleasurable sociability to argue for an emancipatory, even utopian dimension of cruising. By mingling care for the self with care for others, and especially for others with whom we have no prior affinity or acquaintance, cruising offers a glimpse of the social as it could, even should, be. If difference is often the basis of antagonism, the ethic of cruising offers a way to recast it as pleasant and pleasurable. The significance of cruising, not strictly as a sexual practice but as mode of existence, is that it draws attention to both our treatment of others and to our own otherness. It is for this reason that Dean writes that "ultimately the ethics of cruising is an ethics of the stranger in modernity" (177).

This body of work on cruising is crucial to interpreting Proustian sociality. The Recherche, despite its pastoral nostalgia, is a fundamentally urban text. While Proust's narrator largely traverses 
the intricate social networks of the aristocracy and upper bourgeoisie, the novel is just as much defined by its dark matter: the teeming, impersonal mass of citizens into which the narrator, like the Baudelairian flâneur, will sometimes dissolve. As the novel unfolds, the growing pervasiveness of homosexuality begins to charge its urban backdrop with a vague, impersonal queer eroticism. Queer desire runs through the strata of Proust's Paris, linking together the diverse elements of its social body, of which the duc de Châtellrault and the Guermantes' usher are part. The encounter between these two fleeting figures is not only a means to study queer themes in Proust, but to see how queerness inflects his social vision, encouraging novel readings of the relationship between self, city, and society in the Recherche.

Sodome et Gomorrhe marks the point at which homosexuality explodes into the narrative. It is not, however, the cruising scene between Châtellrault and the usher upon which the novel pivots, but the episode immediately preceding it. Perhaps the most famous depiction of cruising in literature, and certainly among the most iconic literary representations of homosexual desire, the encounter between the baron de Charlus and the tailor Jupien that opens the volume is clearly the novel's gay overture. This sequence of around thirty pages frames the narrator as a kind of naturalist, juxtaposing his observation of a bee pollinating a flower with the curious mating habits of two homosexuals. It is effusive, exuberant, overflowing with diverse metaphors and incisive vignettes - so incisive that Francis Bacon felt that the passage said "all that needed to be said about being homosexual" (Gowrie). The narration of the meeting between the duc de Châtellrault and the Guermantes' usher is, by comparison, terse and even forgettable, oddly worked into the narrative and concerning two characters who disappear from the novel after only a few pages. This scene is not merely a reprise of 
the overture to Sodome et Gomorrhe nor a refinement of its themes, though I feel that it is, in some measure, both. Instead, I argue that this passage plays the bivalent role of, on one hand, lucidly recording the habits of Paris' queer sexual public and, on the other, subtly incorporating the novel's major concerns in a way that posits homosexual desire and the pleasure of public sex as inextricable from the novel's structure. Moreover, occuring at the point in the novel at which homosexuality becomes one of the narrator's major preoccupations, we can see how its apparently insignificant details illuminate the veiled queerness of its earlier volumes.

When the passage begins, we have just rejoined the narrator as he arrives at a soirée hosted by the Princesse de Guermantes. After the extended analepsis in which he observes Charlus and Jupien have sex, his own anxieties reassert themselves: he is terrified that he is mistaken, has not been invited to the soirée, and will embarrass both himself and the princess upon being announced by their usher. Yet his narrative is diverted by the presence of another, equally anxious individual:

Il y avait quelqu'un qui, ce soir-là comme les précédents, pensait beaucoup au duc de Châtellerault, sans soupçonner du reste qui il était : c'était l'huissier (qu'on appelait dans ce temps-là «l'aboyeur ») de $\mathrm{M}^{\text {me }}$ de Guermantes. M. de Châtellerault, bien loin d'être un des intimes — comme il était l'un des cousins — de la princesse, était reçu dans son salon pour la première fois. Ses parents, brouillés avec elle depuis dix ans, s'étaient réconciliés depuis quinze jours et, forcés d'être ce soir absents de Paris, avaient chargé leur fils de les représenter. Or, quelques jours auparavant, l’huissier de la princesse avait rencontré dans les Champs-Élysées un jeune homme qu'il avait trouvé charmant mais dont il n'avait pu arriver à établir l'identité. Non que le jeune 
homme ne se fût montré aussi aimable que généreux. Toutes les faveurs que l'huissier s'était figuré avoir à accorder à un monsieur si jeune, il les avait au contraire reçues. Mais M. de Châtellerault était aussi froussard qu'imprudent ; il était d'autant plus décidé à ne pas dévoiler son incognito qu'il ignorait à qui il avait affaire ; il aurait eu une peur bien plus grande — quoique mal fondée — s'il l'avait su. Il s'était borné à se faire passer pour un Anglais, et à toutes les questions passionnées de l'huissier, désireux de retrouver quelqu'un à qui il devait tant de plaisir et de largesses, le duc s'était borné à répondre, tout le long de l'avenue Gabriel : «I do not speak french. » (3:35)

[There was one person who, on that evening as on the previous evenings, had been thinking a great deal about the duc de Châtellerault, without however suspecting who he was: this was the Princesse de Guermantes's usher (styled at that time the "barker"). M. de Châtellrault, so far from being one of the Princess's intimate friends, although he was one of her cousins, had been invited to her house for the first time. His parents, who had not been on speaking terms with her for ten years, had made it up with her within the last fortnight, and, obliged to be out of Paris that evening, had requested their son to represent them. Now, a few days earlier, the Princess's usher had met in the Champs-Elysées a young man whom he had found charming but whose identity he had been unable to establish. Not that the young man had not shown himself as obliging as he had been generous. All the favours that the usher had supposed that he would have to bestow upon so young a gentleman, he had on the 
contrary received. But M. de Châtellrault was as cowardly as he was rush; he was all the more determined not to unveil his incognito since he did not know with whom he was dealing; his fear would have been far greater, although ill-founded, if he had known. He confined himself to posing as an Englishman, and to all the passionate questions with which he was plied by the usher, desirous to meet again a person to whom he was indebted for so much pleasure and largesse, the Duke had merely replied from one end of the Avenue Gabriel to the other: "I do not speak French."] (4: 46)

If the narrator approaches the encounter between Charlus and Jupien with the eye of a naturalist, the tone of the passage above is documentary and even journalistic, closer to that of the many lay chronicles of sexual culture in Third Republic Paris. Gone is the endless proliferation of metaphors for homosexuals: bees, flowers, jellyfish, Israelites, and so on. In fact, the very sparseness of the passage is suspect in the aftermath of such effusion. As Lawrence Schehr points out, in the Charlus/Jupien sequence the narrator's metaphors begin to rebound on themselves: "peut-être l'exemple des Juifs, d'une colonie différente," he wonders, "n'est-il même pas assez fort..." [Possibly even the example of the Jews, of a different type of colony, is not strong enough...] (3:25; 4:33). If the narrator is making such elaborate contortions in order to explain homosexuality and still admits to coming up short, what are readers supposed to make of it? In Schehr's conclusion, "all these half-definitions of homosexuality wind up undefining it" (Shock of Men 71). In Sodome et Gomorrhe I, the narrator burns himself out in an attempt to conceptualize homosexuality; at the opening of Sodome et 
Gomorrhe II, he makes no more attempts to explain it. It simply exists, and the narrator is its impartial observer.

The initial encounter between the duke and usher is, among other things, a miniature anatomy of Paris' queer sexual public and its behaviors. By reading it as such, I am effectively taking Proust's documentary tone at face value. However, I do this only to frame the more theoretical analysis of cruising that will follow. If we can establish the social makeup, conventions, privileged locales, etc. of Paris' Third Republic cruisers, then we can better attend to the complexities of Proust's portrayal of cruising in the Châtellerault episode and the role it plays in the Recherche.

Situating this encounter in the Champs-Elysées, Proust has chosen the Third Republic cruising ground par excellence. In the mid 19th century, this strip of parks, gardens, shops, and cafés was an exemplary space of licit pleasures. It was above all a place of aristocratic spectacle, where men's horses and women's outfits could be paraded around for mutual appreciation and critique (Ross 103). Yet towards the end of the century, public perception had designated the Champs-Elysées as a locus of prostitution and homosexuality. This was due in part to the "faits divers" section of French newspapers, which dispersed accounts of miscellaneous events that did not quite qualify as news. Among these were the arrests of men engaged in public sexual acts with other men, accounts of which offered an upright bourgeois readership a "pervasive sense of impending social disruption" at a safe distance from any actual encounters with sexual marginality (Wilson 193). Contributing to this shift in perception was the trial of the Comte de Germiny, a 35 year old aristocrat arrested for soliciting sex from a teenage, working class boy at a urinal near the park. The trial of Germiny was sensational and had cultural echoes that likely would have reached Proust: "Germinisme" quickly 
became one of many euphemisms for what was usually referred to as pédérastie (or "pederasty," Peniston 152-153).

The Champs-Elysées were also one of the first parts of Paris to see the installation of public urinals, variously called vespasiennes, pissotieres, and in coded gay slang, tasses, or "cups". This program began during the Second Empire with the Haussmannization of Paris, a sweeping public works program that demolished many medieval neighborhoods and constructed vast avenues and green spaces, and continued into the Third Republic. The thousands of urinals flung up across the city were part of an attempt to curb public urination which, once a common sight, was coming to be seen as an issue of public decency. Bound up with this initiative were the evolving notions of public and private space that the ascendant bourgeoisie were projecting onto the city. As this division crystallized in the urban consciousness, the bourgeoisie worked to refashion public space in their own image of propriety. Urinals were only one of many strategies - including the installation of streetlights, the construction of a modernized sewer system, and the de- and reconstruction of cramped and disorderly working-class neighborhoods — to enforce norms of bodily hygiene and appropriate public behavior. Paradoxically, however, men seeking sexual encounters transformed these "facilities intended to facilitate movement towards 'real' destinations into a destination themselves" (Ross 255). The urinals, intended as part of an ideological project that would help determine the rational order of public space and its difference from the private, were instead repurposed by a marginalized sexual public in a way that subverted order and blurred public and private.

This tension about the proper use of public space figures in the Recherche, in which the Champs-Elysées serve as the backdrop for the teenage narrator's budding attraction to his first love, 
Gilberte Swann. Upon entering a public "water-closet" in the park, he feels an indescribable pleasure from its "fraîche odeur de renfermé" [cool, fusty smell] $(1: 483 ; 2: 88)$. He also refers to the female bathroom attendant, who has a questionable "goût pour les jeunes garçons" [taste for young boys] as "la marquise"; perhaps not coincidentally, it was common for gay men as early as the 1870 os to use the feminine forms of aristocratic titles like this one as nicknames (Peniston 105). The sexual charge of this scene is compounded by Proust's suggestive choice of words (see Hayes 1001-1002); he is "penetrated" by an olfactory pleasure that he in turn wishes to "penetrate," and the inclusion of the verb jouir (a verb that generally means "to enjoy", but also, at least as early as the 186 os, "to cum") lends the experience a decidedly erotic subtext. Furthermore, after exiting the water-closet, he and Gilberte wrestle on the grass, leading the narrator to spontaneously ejaculate.

This suite of events points to broader themes in the Recherche regarding the eroticism of public and/or liminal spaces. In Combray, the fictionalized village of the narrator's youth, the narrator masturbates in the bathroom of his family's summer house, a space certainly not intended for erotic pleasure - even if, for many adolescents, the bathroom often becomes the erotic center of the home. To recast the bathroom, through which we are meant to pass only briefly and out of necessity, as a site of pleasure also encourages a rethinking of what constitutes waste, refuse, excess. In many ways, Proust's novel itself is a meditation on, and even manifesto of, what is perceived as wasted or unnecessary, of diversion and digression. There is no reason that bathrooms, piss, and cum should not sit alongside infatuation, social excursions, and the titular "temps perdu" (lost or wasted time) as worthy objects of study and appreciation. 
The novelist was not alone in noticing the draw of waste, though he may have been more sympathetic to it than Félix Carlier, chief of the service des moeurs during the Second Empire, who mused that "cet acharnement à choisir des water-closets comme point de rendez-vous paraîtrait incroyable, si nous ne disions tout de suite que l'odeur qu'exhalent ces sortes d'endroits est une des conditions recherchées par une catégorie fort nombreuse des pédérastes, aux plaisirs desquels elle est indispensable" [this eagerness to choose water-closets as a meeting place appears incredible if we would not immediately mention that the odor that exhales from these sorts of places is one of the conditions sought out by a very numerous category of pederasts, for whose pleasures it is indispensable] (qtd. in Ross 255). For Carlier, the indiscriminate mélange of so many Parisians' odors is related to the erotic mixing that took place in the toilets. He is, however unsympathetically, attuned to the ways in which scent constitutes real, bodily interpenetration; for him, not only is erotic contact precipitated by scent, but scent itself is a kind of erotic contact. Thus, while the narrator enjoys this scent alone, his experience is a social, and even sexual, one, albeit in an indirect, impersonal, and evanescent way. Proust was also aware of the various uses of public bathrooms, and their unique charms to a certain sexual public, when he suggestively juxtaposed the pleasure of their odor with the act of ejaculation. Both sensations are bound up with the contemporary cultural debate over the proper use of public space, a debate founded in bourgeois notions of propriety that the narrative subtly challenges. We can even cite the spontaneity of the narrator's ejaculation as indicative of the unpredictability of urban space and its resistance to strict regulation.

More important here, however, is the way in which Proust portrays the link between marginalized sexuality and marginal space. Homosexuals (along with prostitutes and other sexual 
publics) constituted a kind of social dark matter in Third Republic Paris, barely perceptible yet disproportionately threatening. They haunt about the shape of Proust's novel until, to borrow from Monique Wittig, the beginning of Sodome et Gomorrhe sees them erupt as if from a Trojan horse, eventually filling every nook and cranny of the narrative (see Wittig 73-74). The encounter between Châtellrault and the usher in the Champs-Elysées is, in this sense, a reprise of earlier (hetero)sexual themes that retroactively throws into relief their covert gay subtext.

Proust's narrative of this encounter also serves as a document of the social conventions of cruising, particularly in regards to age, class, and monetary exchange, one that other sources from the era corroborate. According to William Peniston, one of the first scholars to extensively study male-male sex in the archives of the Paris police, cruising encounters were usually marked by sharp differences in age. In a comparison of 183 cases of male couples arrested together, all dating from the 1870 s, "34 percent had an age difference of one to ten years" while " 45 percent...had an age difference of more than eleven years" (111). Although Proust's narrator does not supply us with the ages of the duke or the usher - age in the Recherche is notoriously slippery in any case — he does note that "toutes les faveurs que l'huissier s'était figuré avoir à accorder à un monsieur si jeune, il les avait au contraire reçues" [all the favours that the usher had supposed that he would have to bestow upon so young a gentleman, he had on the contrary received] $(3: 45 ; 4: 46)$. Not only does this suggest that the usher is significantly older than the duke, but that among this particular sexual public, it was usually the older man who would pleasure the younger without necessarily expecting reciprocation. As Peniston observes, Paris' queer sexual subculture was not only youthful, but prized and sought out young men, often for a fee (114). 
Class difference was equally as marked between cruisers, a pattern that overlaps and interacts with that of age difference. Once again, the encounter in Proust is atypical; when older and younger men were arrested together, the older man was usually wealthy and the younger working class. Members of the elite were rarely found with the serving class, presumably for fear of the exact situation in which Châtellrault finds himself at the Princesse de Guermantes' soirée (115-116). Instead, elites were drawn to poor, young laborers who, as Daniel Guérin recalls in an interview with Gilles Barbedette and Michel Carassou, "étaient plus près de l'animalité" [were closer to animal nature] and for whom any sexual act, regardless of gender, was indicative of "une surabondance de virilité dont on n'avait pas à rougir" [an excess of virility which was nothing to be embarrassed about] (Barbedette and Carassou 48, my translation). In conversation with the same, Edouard Roditi adds that "certains...étaient fétichistes aussi de l'habillement ouvrier" [some...also fetishized the clothing of workers] along with the uniforms of sailors, members of the military, and others that connotted masculinity and virility (8o, my translation). Charlus manifests this penchant in the Recherche, and his attempts to groom and ennoble his working class lover Morel confirms another pattern that Peniston identifies: while cruising encounters were characterized by the crossing of class lines, long term friendships and relationships were almost always uniform in terms of class (109).

Many working class men engaged in prostitution, yet monetary exchange was often voluntary and situational. Exchange was most common in cross-class encounters, and was driven more by convention than by demand. In this way, the money and gifts that elites would offer their partners after a hookup constituted a kind of loosely-knit economy within the diverse sexual public. If we read the duke's "favors" as financial rather than sexual, we can then glimpse the workings of this 
informal market, the pliability of its conventions, and its unstable dependence on the legibility of "socio-sexual codes of exchange" (Ross 113). Importantly, the text leaves ambiguous the question of whether the duke's generosity is due to an altruistic impulse, his reading of the usher's class codes, or is simply a means to satisfy his own sexual desires. It is fitting, then, that Andrew Israel Ross cites this precise passage when he argues that "same-sex sexual activity in nineteenth-century Paris cannot accurately be placed into 'for pleasure' and 'for profit' categories" (113-114).

While Jeffrey Weeks refers to these kind of interclass interactions as "a form of sexual colonialism" (56), they also resist such a reductive characterization. It is important to question whether pleasure is being derived at the expense of any participant. At the same time, the various axes of social inequality need not determine the power differentials of a given encounter. In fact, the unstable relationship between pleasure and profit is indicative of the ways in which cruising can render social conventions and hierarchies more plastic. This is especially true of Third Republic Paris, where sexual identities were far from ossifying into their modern forms, the social order was in flux as the aristocracy withered, and bourgeois norms had not yet completely permeated the working class consciousness. In this context, cruising privileges a loose and permissive kind of contact between urban cohabitants. This kind of contact, much like that which Samuel Delany theorizes in Times Square Red, Times Square Blue, imbues interactions among strangers with unquantifiable benefits including, but not limited to, pleasure. Furthermore, it directly contradicts the predominantly bourgeois equation of stranger with danger. The practice of cruising is capable of facilitating free association among a diverse urban public, indiscriminately mingling different classes, ages, and races, and destabilizing the public/private distinction that governs the use of space. 
It was precisely this sort of inter-class mingling that shocked the Goncourt brothers, a pair of novelists whose collaborative journals scrupulously documented fin de siècle Paris, when they visited the Café de l'Eldorado in the 186os. The visit left them convinced that café-concerts and other such spaces were "destroying the moral and material foundations of Paris" (Peniston 138-139). From a different perspective, such social mixing is a quasi-utopian response to modern urban alienation, engendering forms of relationality that take otherness, rather than similarity, as their common denominator. Yet unlike the goings on in such cafés, the practice of cruising is spatially unbounded. As Mikhail Bakhtin says of the carnival, it "knows neither stage nor footlights" (Bakhtin 128). This means that the sheer existence of cruising brings a suggestion of eroticism to the most innocent urban stroll, making a libidinous object out of sociality itself.

At the same time, the socio-sexual misalliances that cruising facilitates are almost always fleeting. The loose and evanescent nature of its social bonds means that the cruising encounter rarely challenges the city's "moral and material foundations" at the magnitude that observers like the Goncourts feared. However, this is not to say that it does not have an effect on them. The intimacy, care, and generosity that inhere in casual sex can persist beyond a specific encounter, suggesting different ways of living with the urban other. Such practices encourage forms of community and modes of exchange that resist a transactional view of social relations, the exact view that drives so much of Proust's narrative. Even more, they imply an urban queer ethic running counter to bourgeois morality, one which entails a more democratic understanding of public space and social relations. While public sex very often retains a transactional element, the ethic I describe is located in the affective excess of this schema, in what happens in spite of it. It is this excess that complicates the 
assertion that sex between men of different ages and classes is simply exploitative. As we will examine in more detail later, the passage from the Recherche which is the subject of this thesis exemplifies Proust's ambivalence towards this ethic.

Finally, anonymity is crucial to understanding cruising's particular kind of socialization. The encounter between the duke and usher is typical in that names are not exchanged, hence the anxiety over naming when they meet again at the soirée. This disorientation is the result of more than a change in surroundings, but a metamorphosis of social identity. As I outline above, many scholars of cruising explore how the practice encourages us to be temporarily less than ourselves. In such encounters, after all, it is not only the other but ourselves who are reduced to anonymous, interchangeable strangers. Such a state of lessness can be a source of liberatory pleasure, as well as of the queer urban ethic mentioned above (Ensor 156). Furthermore, a mode of existence that is, if only momentarily, detached from identity can allow one access to pleasures and behaviors that are "not immediately commensurate with who one is understood to be" (158). This is particularly important in the context of fin de siècle France, where sexual identity itself was emerging from the craze for taxonomy in the medical and criminal justice fields, categorizing, and often pathologizing and criminalizing, the desires of what was by many accounts a sexually diverse and permissive urban working class. In this thesis, however, I emphasize the importance anonymity in a Proustian setting characterized by its reflexive attention to language itself, and especially to names and naming. Moreover, since aristocratic titles are at play, the passage at hand offers a privileged opportunity to explore the nuanced relationship between sexuality and class in the Recherche. 
The preceding overview of both the culture of cruising in fin de siecle Paris and the recent queer scholarship on cruising will underpin the claims of this paper. It also affords me the opportunity to furnish some historical basis for Proust's portrait of the cruising encounter, so that it can be read with and against the contemporary accounts that survive in the form of police archives, guidebooks, interviews, novels, and so on. Yet most importantly, it offers a sense of the fluidity, often surprising to modern readers, of sexual behavior in Proust's Paris. Despite the aggressive policing of the city's service des mours and the outrage of its upright middle class, Proust was still able to document and interpret the vibrant public sexual culture that would dwindle in the decades after his death. It was a culture that was subtly, even unknowingly, at battle with the paranoid forces of social order. In their necessary commitment to mutual exposure, the individuals from disparate classes, age groups, and regions of France and beyond that made up this culture proposed a democratization of civil life that pushed the boundaries of republican ideals.

\section{BETWEEN MEN: SEXUALITY ON THE THRESHOLD}

Sexuality in Proust is in many ways inextricable from the question of boundaries: of what belongs where, of where we belong, and of what is and is not part of us. Anxieties over inside and outside, and the impossibility of lingering on the threshold between the two, defines many instances of queer sexuality in the Recherche. These anxieties are not just architectural, but call into question the 
limits of our physical bodies and psychic selves, and our supposed autonomy within the urban amalgam. As we will see, the notoriously hermetic Proust repeatedly defies any pretense to closedness.

In the passage in question, the architectural threshold can be seen as metaphorizing other kinds of liminality. Bearing this is mind, let us turn back to the text, attending specifically to its setting:

Ayant à répondre à tous les sourires, à tous les bonjours de la main qui lui venaient du salon, il n'avait pas aperçu l'huissier. Mais dès le premier instant l'huissier l'avait reconnu. Cette identité qu'il avait tant désiré d'apprendre, dans un instant il allait la connaître. En demandant à son «Anglais » de l'avant-veille quel nom il devait annoncer, l'huissier n'était pas seulement ému, il se jugeait indiscret, indélicat. Il lui semblait qu'il allait révéler à tout le monde (qui pourtant ne se douterait de rien) un secret qu'il était coupable de surprendre de la sorte et d'étaler publiquement. En entendant la réponse de l'invité : « Le duc de Châtellerault », il se sentit troublé d'un tel orgueil qu'il resta un instant muet. Le duc le regarda, le reconnut, se vit perdu, cependant que le domestique, qui s'était ressaisi et connaissait assez son armorial pour compléter de lui-même une appellation trop modeste, hurlait avec l'énergie professionnelle qui se veloutait d'une tendresse intime : «Son Altesse Monseigneur le duc de Châtellerault ! »(Proust 3:37) 
[Having to respond to all the smiles, all the greetings waved to him from inside the drawing-room, he had not noticed the usher. But from the first moment the usher had recognised him. The identity of this stranger, which he had so ardently desired to learn, in another minute he would know. When he asked his 'Englishman' of the other evening what name he was to announce, the usher was not merely stirred, he considered that he was being indiscreet, indelicate. He felt that he was about to reveal to the whole world (which would, however, suspect nothing) a secret which it was criminal of him to force like this and to proclaim in public. Upon hearing the guest's reply: "Le duc de Châtellerault," he felt such a burst of pride that he remained for a moment speechless. The Duke looked at him, recognised him, saw himself ruined, while the servant, who had recovered his composure and was sufficiently versed in heraldry to complete for himself an appellation that was too modest, shouted with a professional vehemence softened by an emotional tenderness: "Son Altesse Monseigneur le duc de Châtellerault!”] (4:49-50)

The entire interior drama in which Châtellrault, the usher, and the narrator participate plays out in silence on the threshold of the Princesse de Guermantes' mansion. Crossing the threshold marks a transition from public to private space, as well as from a public into a more closed social system. By virtue of the characters' class difference and sexual affinity, this transition entails a collision between axes of difference that underscores the norm of the boundary. Both Châtellrault and the usher are part of a specific urban sexual public: an informal, open-ended community of shared desires, one made up of "unsystematized lines of acquaintance" comprising "more people than can be identified" (Berlant 
\& Warner 558). They demand no membership, only recognition, a mutual intelligibility of their particular signs, gestures, gazes (Ross 95-96). If publics emerge through such aimless, anonymous signaling, the more private space of the soirée is characterized by its very deliberate filtering-out of strangers. As such, naming oneself and in turn being named to the host and attendees is a precondition for crossing over into its aristocratic world.

Similar thresholds appear in relation to sexuality throughout the Recherche. Only pages before, we witness Jupien cruising Charlus from the door of his shop. Despite the unambiguous eroticism of their interaction, Charlus partly conceals his desire in a series of small performances; we see him "sifflotant d'un air fanfaron, non sans crier 'au revoir' au concierge qui [...] ne l'entendit même pas" [boldly humming a tune, and not forgetting to fling a "Good-day" to the porter who...did not even hear him] before pursuing Jupien. He asks the tailor for a light, but then pretends to realize that he has left his cigars. Blustering and poorly feigning indifference (just as he does when cruising the narrator in the seaside town of Balbec earlier in the novel), Charlus hesitates until he secures an explicit invitation into the Jupien's home: "Entrez, on vous donnera tout ce que vous voulez" [Come inside, you shall have everything you wish] (Proust 3:8; 4:8-9). Their heavily coded interaction refuses to acknowledge sex. However, as the narrator points out, "la beauté des regards de M. de Charlus et de Jupien venait, au contraire, de ce que, provisoirement du moins, ces regards ne semblaient pas avoir pour but de conduire à quelque chose" [the beauty of the reciprocal glances of M. de Charlus and Jupien arose precisely from the fact that they did not, for the moment at least, seem to be intended to lead to anything further] $(3: 7 ; 4: 7)$; in other words, their cruising does not necessarily need to take 
sex as its telos in order to have a pleasure and beauty all its own. We can therefore imagine cruising itself as a threshold onto an array of sexual, social, and other possibilities.

The theme of sexuality on the threshold returns in the novel's final volume, Le temps retrouvé, where the narrator watches two "very elegant" friends linger at the threshold of Jupien's male brothel, neither able to confess his anxieties nor push ahead (4:401; 6:191-92). This scene, however, inverts that of Châtellrault and the usher. Here, two men of an elevated social rank and who know each other well—if not well enough to speak openly about their sexual desires, at least enough to get as far as the door of a brothel - attempting to enter a space, their presence in which will code them as members of a queer sexual public. However, they are also queered by their liminal position. The psychic threshold of expressing queer desire is mirrored by the real, definitive threshold of the brothel doorway, leaving them mired in uncertainties that the narrator, who has crossed the threshold, no longer shares (Lucey 195). Not only does this fleeting passage, with its attention to spatial relations, underline how sexual marginality often occupies marginal spaces, but also how the queerness of the border contrasts with the normativity of the public/private boundary, even if the other side of the threshold is alive with queer sex. Such a reading may explain why the supposedly heterosexual narrator can comfortably observe the two friends' struggle even from the interior of the brothel.

While the nature of the threshold and the position of the narrator have been inverted in comparison to the episode of the Guermantes' soirée, the unspeakability of queer desire remains unchanged. The "quoi! Après tout, on s'en fiche?” [“Well! After all, what do we care?"] repeated by one of the young men encapsulates the tautological loop that neither is willing or knows how to 
escape. The question, posed with a "sourire mi-interrogateur, mi-destiné à persuader" [a smile that was half a question and half an attempt at persuasion], indicates on the one hand a sincere curiosity (as if they are asking: "Do we care? About what? Why? What does it mean to be here?"), and on the other a hope that the one of them will finally break the loop and cross the threshold (Proust 4:401; 6:191). What are the two friends actually waiting for? Perhaps, like Charlus in the courtyard, they are anticipating some pretext that can spare them from having to acknowledge their desires. Perhaps they are waiting, without knowing it, for the queer space itself to render them strange to one another, for the very structure of the brothel to redefine the parameters of their relationship.

How might this happen? As those who frequent bathhouses today know well, to enter one must cross a series of thresholds and transitional zones. From the reception area, one passes through ceremonial doors and curtains, usually into a locker room, and sometimes through heavier curtains of leather or plastic, passage through which signifies nonverbal consent to the goings on beyond. Often, guests must forfeit their identification, a security measure that nonetheless points to the bracketing of identity inherent in such spaces (as does the typical bathhouse uniform: a towel around the waist, or nothing). After this series of gauntlets, friends who arrive together often part ways only to reconvene, unrecognized, pleasuring each other in a dark room or through a glory hole. If the two friends' reticence speaks to the difficulty of expressing queer desire in Proust's work (Lucey 193), the anonymous intimacy just described embodies the relief of this difficulty by rendering expression unnecessary. One does not need to attribute queer desire to oneself if the environment itself sanctions it, and/or if the expression of desire plays out anonymously rather than in the arena of identity. Such a 
relief is the mirror opposite of the anxiety around being named, identified, and effectively outed that wracks Châtellrault and the narrator as they are swept reluctantly towards the Guermantes' usher. It should be noted that the two friends' situation is not exactly typical. As Michael Lucey points out, they have somehow found out from a third party the location of the brothel, decided for any number of reasons to go together, and more or less committed to having some kind of sexual experience with other men (194-95). A more typical encounter, such as a fleeting jack-off session in a "tasse" or behind a tree in the Champs-Elysées, would instead be predicated on anonymity. Moreover, it would be less likely to entail a normative boundary between queer and not-queer space than a queering of public space through sex. This is to say that a site like a "tasse," which is paradoxically both non-sexual and erotically charged, can be entered without implying anything more than a full bladder. Even the would-be cruisier may have no intention of giving or receiving pleasure: he may be the recipient of a surprise advance, may emit signs of sexual interest in spite of himself, or may walk into an encounter that is already taking place. Because their boundaries are mobile and psychic rather than fixed and architectural, the identitarian stakes of public encounters are lower, thus facilitating greater sexual fluidity.

Here, rather than crossing a queer threshold, the cruiser is himself crossed by it. We can compare this to Proust's narrator feeling "penetrated" by the pleasurable odor of the toilet, engendering his own desire to "penetrate" in turn $(1: 483 ; 2: 88)$. This is part and parcel with my earlier characterization of cruising as non-teleological; while it is most easily defined as the act of looking for sex, it is just as likely that sex will not be found as that an "innocent" interaction will unexpectedly become a less innocent one. If we allow ourselves to perceive cruising as something 
other than goal-oriented, we can better understand how fin de siècle Paris boasted such impressive sexual fluidity. As Daniel Guérin recalls in an interview with Gilles Barbedette and Michel Carassou, Paris of the teens and '20s was full of "des gars entre vingt et trente ans, tous célibataires et absolument pas froissés si on manifestait à leur égard quelconque désir homosexuel. Tout leur était naturel à l'égard du sexe" [guys between twenty and thirty years old, all single and absolutely unfazed if one expressed some homosexual desire to them. Everything was natural to them in regards to sex.] (Barbedette \& Carassou 47, my translation). Guérin also notes a lack of specifically gay neighborhoods, highlighting how homo- and heterosexuality coexisted on the same streets and even in the same establishments (49). Such mixing between different publics poses a challenge to normative boundaries such as the brothel doorway, and suggests that the chance encounter between the usher and Châtellrault may have been far more exemplary than the premeditated brothel excursion in Le temps retrouvé.

We do not know what happens to the two friends on the threshold, only that they shortly appear on the other side upon, to use Proust's own suggestive term, "penetrating" the brothel (4:402; 6:193). We can, however, theorize what happens to Châtellrault. In order to parse out the complex play of recognition and naming taking place, I will be helpful to turn to another Proustian theme which may seem largely unrelated: the "queer little gods" that populate the Recherche, the presence of which Eve Sedgwick argues "characterizes the vital atmosphere of Proust reading more than its landmark moments" (Sedgwick 15). Perhaps these marginal, liminal entities, omnipresent but easily overlooked, can offer some insight into that other universal but largely unseen "race" who occupy the margins of Proust's Paris. 


\section{"QueER LitTLe GODS": ON THE SPIRIT OF CRUISING}

The Recherche abounds with references to minor deities, spirits, homunculi, and other beings drawn from numerous pre-Christian religious traditions. These entities play a variety of roles. Members of the aristocracy are often compared to mythical beings, pushing the talismanic draw that they exert on the narrator into the divine realm. Sometimes they inhabit foreign objects, elements of nature, and even ourselves. On countless occasions Proust attributes thoughts, emotions, and even utterances to miniature persons who live inside us and exercise any number of highly specialized functions, from measuring barometric pressure to even helping cruisers identify one another. Pericles Lewis has argued that Proust's frequent references to pre-Christian religion reveals how the "seemingly hermetic inner world" of the artist is shaped by the real forces of the social world ("Marcel Proust" 82). In focusing Lewis' lens on the public culture of cruising, I argue that homosexuality and queer forms of socialization are as informed by this divinity-field as any other Proustian theme, and that the episode of the duc de Châtellrault is exemplary of this relation.

Proust establishes such a link explicitly in the early pages of Sodome et Gomorrhe:

Le vice (on parle ainsi pour la commodité du langage), le vice de chacun l'accompagne

à la façon de ce génie qui était invisible pour les hommes tant qu'ils ignoraient sa 
présence. [...] Ulysse lui-même ne reconnaissait pas d'abord Athéné. Mais les dieux sont immédiatement perceptibles aux dieux, le semblable aussi vite au semblable, ainsi encore était M. de Charlus à Jupien. (3:15)

[Each man's vice (we use the term for the sake of linguistic convenience) accompanies him after the manner of the tutelary spirit who was invisible to men so long as they were unaware of his presence. [...] Ulysses himself did not recognize Athena at first. But the gods are immediately perceptible to one another, like as quickly to like, and so too had M. de Charlus been to Jupien.] (4:18)

Part of what is striking in this passage is the way Charlus and Jupien's "vice" is split off from them and animated, figured as a more or less autonomous being. However, the metaphor that follows seems to mend this splitting by positing the cruiser not as a man accompanied by a spirit, but as a deity himself. This poses questions on the nature (vs. nurture) of sexuality in Proust by throwing into doubt exactly how one's "vice" relates to oneself and what degree is desire an innate part of us. More radically, however, it demarcates sexuality in a way that, rather than relegating it to some somber margin, exalts it as divine, recasting the fires of the ruined Sodom as beacons of recognition.

For the purposes of this piece, it is important to tease out how this portrayal of Charlus and Jupien's “vice" illuminates the nuances of the Proustian self. From the first pages of the Recherche, the narrator's self leads a multiple existence, as when he feels that he has become, on the threshold of consciousness, the subject of the book he was reading, be it a church, a quartet, or something as abstract as "the rivalry between François I Charles-Quint" (1:3; 1:1). Elsewhere, he treats various 
faculties, memory among them, as separable from himself, while even the structure of the novel troubles the relation between the self who writes, the self who narrates, and the self (or selves) who are narrated. Very often in Proust's novel, these elements of the self take the form of tutelary spirits or génies. Importantly, génie in French connotes not only "genius," as well as the sometimes malicious genie of Arabian tradition, but also a variety of guardian or protective spirits that inhabit people and places and perform a range of benevolent functions (from here on, the italicized génie will carry this meaning). According to Eve Sedgwick, the tutelary spirit in the Recherche both is and is not identified with the self, "animates from within and stands as distinct from the place or person to whom it belongs," and can manifest "for the blink of an eye, or may develop a sustained and modulating presence" (Sedgwick 17). If in the passage quoted above such a being can serve as a metaphor for the faculty of "gaydar," then perhaps we can go further to understand as queer the ways in which they blur the bounds of the self, mediating, with or without our knowledge, our relation to the outside world, and bringing attention to the porosity not only of our physical bodies, but of our psychological and social selves.

As Lewis argues, the Proustian self is already far more porous than the writer's infamous room on the boulevard Haussmann, insulated with cork against dust and noise so that the author could work undistracted, would lead us to believe. Vincent Descombes writes that Proust displays an "exceptional sociological flair" as do other French thinkers such as Durkheim, "for whom the first principle of a sociological view of things is that the group precedes the individual" (qtd. in Bidou-Zachariasen 34). He proves an effective theorist of the self as a "site of competing social roles and identifications," and the privileged place accorded to signs in his work (explored by Deleuze in 
Proust et les signes) can easily cast him as a precursor of symbolic interactionism, a fundamental sociological theory still prominent today ("Citizens of the Plain" 129). The Proustian génie often serves as a bridge between the individual and the social, the inner and outer world, through a mystification and localization of the invisible social forces that shape and constitute our identities ("Marcel Proust" 85). Whereas the mirror episodes of the Guermantes' soirée and the friends at the brothel door exaggerate the anxiety of inside and outside and the difficulty of moving from one to the other, the génie, by occupying both simultaneously, recasts the boundaries of our homes, our bodies, and even our psyches as porous and mutable (Sedgwick 13-14). As such, we may say that the génie incarnates the queerness of the threshold. It serves as a kind of guardian spirit, even a psychopomp, lubricating movement between both physical and psychic spaces. Because of this transitive role, the génie occupies the spaces in between, operating on the margins of experience, and thus suggesting an affinity with the marginal and provisional spaces of cruising.

Furthermore, the figure of the génie integrates Proust's "sociological flair" with his Neoplatonic worldview. In Proust's era, France was awash in new translations of Plotinus, Proclus, and other philosophers of late antiquity, giving a foothold to Platonic thought's mystical leanings. The revival of Neoplatonism would also play a role in the rising popularity of esotericism in the early 20 th century, especially in modernist literary circles. Proust himself was inspired by the Platonic dialogues, especially The Symposium and Timaeus. Moreover, some of his greatest intellectual influences such as Ralph Waldo Emerson and Henri Bergson (who married into Proust's family, the novelist serving as his best man), were deeply indebted to Plotinus. While relatively little critical 
attention has been afforded to the role of Neoplatonism in Proust's work, the Recherche is infused with its thought, and Proust's mystified view of the social is evidence of this philosophical parentage.

Proust seems to refer to the key Neoplatonic principle of the One, the absolute unity and common origin of all things, when he writes that "peut-être...même [n'existe-t-il] qu' une seule [intelligence] dont tout le monde est co-locataire" [perhaps indeed there exists but a single intelligence of which everyone is co-tenant] $\left(1: 55^{8} ; 2: 195\right)$. More often than not, however, we glimpse this concept only sidelong in his frequent evocations of metempsychosis, or the transmigration of souls (see Sedgwick 6-7). The notion of individual selves emerging from and returning to some ineffable, primordial unity, whether through death, sleep, ecstasy, of even a change in social status drives Proust's metaphysical vision. The immutable titles of the aristocracy, for example, are occupied by a succession of different individuals, the map of society merely overlaying a shifting and impersonal social mass that wells up in successive incarnations of, for example, the Duchesse de Guermantes. Proust's kaleidoscopic society, with its sudden rearrangement of apparently immutable hierarchies in a kind if endless cyclicality. (Its karmic echoes that bring to mind Neoplatonism's consanguinity with Hinduism and Buddhism, a relationship that spans Plotinus' enlistment in the Roman army in order to study Indian belief systems to Schopenhauer's popularization of the same in modern Europe.) Love functions similarly: each loved person is little more than a vessel for the lover's own faculty of infatuation, and it is no coincidence that love in Proust so strongly resembles religious idolatry. Even the self is subject to countless deaths and reincarnations over the course of a lifetime, and each self to further subdivision. The narrator of the Recherche, like the protagonist of Hardy's Well Beloved (which Proust knew well), could be described as "one that gave objective continuity and a 
name to a delicate dream which in a vaguer form is more or less common to all men, and is by no means new to Platonic philosophers" (Hardy iii). Therefore, if members of the nobility, lovers, and our intellectual and emotional faculties are often compared to spirits, it is because all are emanations of an unseen force, which is legible only so long as it coalesces around a privileged individual, object, or phenomenon.

Proust's synthesis of the social and the supernatural, as Pericles Lewis points out, has parallels not only with the Neoplatonic One, but also with Durkheim's idea of mana as an "anonymous and impersonal force" ("Marcel Proust" 84). However, readers of the Recherche do not perceive this force directly, but only certain embodied emanations of it. Late in the novel, for example, the narrator reveals heretofore unseen affinities between the disparate elements of his life, such as the circuity of the Guermantes and Méséglise ways, or the genetic union of high and low society in Mlle. de Saint-Loup. The very differences that drive the narrator through the novel and constitute his worldview are thus reconciled within an irreverent and interminable karmic system. The objects of his fascination and obsession— the different paths, infatuations, society figures that animate his thought and behavior - are themselves arbitrary. Yet it is their very interchangeability, like that of strangers cruising the streets, that suggests the monadic source from which they, and the narrator's desire for them, spring.

The génie serves as a window into these social and spiritual dynamics at the heart of Proust's world. With their wholesale disregard for parameters of all kinds— space, time, the self, etc. - they offer the narrator visions of his world's hidden unity, of its absolute resistance to binarism and fixity. Sedgwick writes that the "tutelary genius, unmotivated except by the universal Good, occupies an 
economy of plenitude, of gifts without exchange, of nondualistic relations between internal and external." She contrasts this génie with the "genie" of the Arabian Nights, another being that appears in the Recherche, which is entirely external to us and "available, unlike tutelary gods, to be viewed through the lens of motivation" (19). This genie is an appropriate model for the kind of socialization that the narrator engages in, driven by the desire to know and possess a series of individuals with totemic significance, from Gilberte to Albertine to the Duchesse de Guermantes. The génie, on the other hand, recalls a different and less visible kind of socialization in Proust: cruising.

As I mention above, the génie challenges boundaries, whether architectural, physiological, or ontological. While such porosity may be disconcerting (especially for the asthmatic Proust, writing between a series of cholera outbreaks in 1800 s Paris and that of influenza in 1919, or for us in the wake of AIDS), we can easily rethink this threat to our self-containedness as liberatory. After all, it is precisely in identitarian lessness, a state of being less-than-ourselves, that scholars such as Leo Bersani have located an ethics of cruising. Can an ethic of this type be located in Proust? So far we have framed the "anonymous and impersonal" One as animating the social in Proust, and the génie described by Sedgwick as a more active, but benevolent, manifestation of this force. However, the world in which the narrator moves, obsessed with status and driven by self-interest, obscures and trivializes sociability and the pleasure that comes with it. The Recherche makes a great deal of high society's emptiness, and has little esteem for friendship. So where, if anywhere, do we see the social world redeemed, especially in a way that can be read as ethical? 
While the novelist may not supply us with a madeleine moment—-the quintessential Proustian leitmotif-in regards to the social, Leo Bersani's characterization of the cruising encounter seems to describe exactly the kind of abstract force that permeates the Recherche:

A non-masochistic jouissance [...] is the sign of that nameless, identity-free contact — contact with an object I do not know and certainly do not love and which has, unknowingly, agreed to be momentarily the incarnated shock of otherness. In that moment we relate to that which transcends all relations. (21)

The pleasure, or jouissance, of the encounter arises in part from its transcendence of social relations, the way in which its participants experience the shock, not of the Other, but of "otherness." This is to say that, while cruising, we are not looking for another, but for any and all others. (To seek something specific in a park or bathhouse is more often than not simply cruising for disappointment.) Far from the fetishism that drives so much of the Recherche, cruising's economy of pleasure is centered neither on the self nor the other. As John Paul Ricco observes, queer sexual drive is best understood neither as centripetal nor centrifugal, but as a kind of resonance. Ricco specifies that this resonance is not inter-subjective, but emerges from the "excess and entropy of sociality" itself (Ricco par. 9). The jouissance of otherness is, in this case, a kind of excroissance of the sphere of familiar relations that we most readily associate with the social. To understand cruising's pleasure as social excess, collecting outside of the institutions that structure and regulate social behavior (salons, clubs, and so on), brings us back to Proust's appreciation of waste and excess in general, and more specifically to the spaces of refuse to which Parisian cruisers were drawn. This suggests a thematic ligature between the 
overarching theme of "lost time", the abstract jouissance of cruising, and its attendant bodily and olfactory stimulation.

Proust's understanding of Neoplatonism can help us to better plot such thematic connections. The open-ended language that Bersani and Ricco employ to describe anonymous, queer sexual encounters echoes the early Emerson of Nature, whose influence serves as a link between Plotinus and Proust. Emerson inherits Plotinus' description of thought as "flight," a kind of contemplation that reconciles opposites, resists binarism, and mixes "ephemeral and material registers of existence together in a restless dynamism" (Stanley 461). For Emerson, the sometimes frightening "shock" of flight is allayed by a firm grounding in the material world, such that "ecstatic unions that merge spirit and substance make way for illuminating surprises" (461). This is to say that the "flight" of thought is, for Emerson, preceded by a physical sensation, and cannot be understood as something disembodied or purely intellectual. Part of his project as a reader of Plotinus is to bring the body and senses back into the picture, to tease out the viscerality of Plotinus' "spermatic" writing (Emerson, qtd. in Stanley 461).

This strain of thinking is on full display in Proust's intensely contemplative, but also highly and sometimes unbearably sensual, novel. In fact, the madeleine episode is emblematic of such an Emersonian experience, one in which the body, the spirit, the physical world, and what it conveys to us are so deeply interwoven as to be confused, even indistinguishable, its discoveries originating from an initial physical shock. Kate Stanley notes that many scholars believe Emerson's influence on Proust to have diminished over time, since the former's name appears often in early writings and letters but only once in the Recherche (459). While her study on Emerson's role in the Recherche effectively 
disproves this claim, it will be helpful to turn briefly to Les Plaisirs et les jours (1896), Proust's first collection of novellas and prose poems. It is in one of the stories therein that we can see more explicitly how this Emersonian strain in his writing can play out in the social sphere, rather than in relatively ascetic contexts like the solitary taking of tea in "Combray I."

The story in question, "Un dîner en ville," comprises two sections: in the first, the protagonist, Honoré, explains to a young guest at a dinner the backgrounds of those invited, then a brief coda sees Honoré leaving the dinner to wander Paris alone. The first section's caustic portrait of high society gives way to a kind of ecstasy in the second, with Honoré feeling "great joy" at his unfettered thought which circulates ecstatically beyond the "barriers of impossibility" (102; 106). The passage appears to take some inspiration from Emerson's famous "bare common" in Nature (Emerson 10), but Honoré's ecstasy is not only physical and spiritual, but social. "Chaque personne à qui [Honoré] pensait lui devenait irrésistiblement sympathique" [each person he thought of immediately struck him as irresistibly likeable], and as he winds through the streets hoping for some (any?) encounter, "si ses prévisions s'étaient réalisées, il eût abordé l'inconnu ou l'indifférent sans peur, avec un tressaillement doux" [if his expectations had been realised, he would have gone up and greeted strangers or indifferent passers-by fearlessly, gently, and with a quiver of anticipation] $(102-103 ; 107)$. In contrast with Proust's cynical portrait of the hermetic society dinner, in which the presence of a stranger necessarily signifies some machination on the part of the host (97; 101), here Honoré experiences an entirely different kind of sociability, in which the very strangeness or indifference of those around him provokes a distinctly sensual pleasure. He even makes the potentially suggestive move of opening his topcoat, so that passersby might appreciate his well-fitting outfit and 
the carnation in his buttonhole (103;107-108). Honoré's stroll is marked by an openness both physical and psychic, with neither one preceding the other, and both characterized by a feeling of non-teleological possibility, a Kantian "purposiveness without purpose" (Dean 210).

Certainly the Proust of "Un dîner en ville" owes a debt to the Baudelairian flâneur as much as to Emerson. At the same time, he toys with the flâneur's detached gaze by introducing cruising's element of reciprocity (Ross 93-94). Honoré is certain (rather like the speaker of Baudelaire’s "A une passante") that passersby reciprocate his goodwill, and gives himself over to "l'admiration des passants, à la tendresse dont il était avec eux en voluptueux commerce" [the admiration of the passers-by and the affection which he so voluptuously exchanged with them] ("Un dîner" 103; 108). While this passage may not describe cruising necessarily, the open topcoat and sexual connotation of "voluptueux" lend some eroticism to what is already a "physical well-being" (103; 107, emphasis mine). Moreover, in a sexually-charged Paris in conflict with bourgeois propriety, "the pleasures of the innocent promenade always threatened to become the sexual pleasures of the streetwalker" (Ross 86). Honoré's ability to wave through crowds of strangers "fearlessly" may well indicate his openness to a sexual encounter, as might his mild exhibitionism.

Yet in Honoré's aimless promenade, the opening of his top coat is not only an erotic gesture, but a practice of exposure in a broader sense. Often, the chaos of city streets challenges our physical boundaries, appearing to threaten us with violence, contagion, or some more banal kind of befoulment; Honoré's stroll recasts this exposure — social, affective, erotic — as pleasant, desirable. His promenade is a glimpse of an urban ethos marked by a non-oppositional relationship between safety and risk, another element of cruising's ethics that Tim Dean outlines (190). The impersonal 
fraternity that Honoré feels for the crowd around him challenges the assumption on the part of an economic elite that public space should conform to their values of propriety and privacy, a belief that heaps of indignant letters to the local government from Parisians fed up with seeing sex workers roam freely bear witness to Ross 126-137). Of course, Honoré is very much part of this elite. He loses interest in them, however, when his attention shifts to the margins of urban life, which is to say, everyone else. Rather than exporting the attitude of one public (the dinner) to another (the streets), Honoré makes a liberating transition between the two, the inverse of which we see in Châtellerault.

This kind of fluidity, Honore's capacity to feel affinity on the basis of, rather than in spite of, difference, recalls Emerson's proposition that the delight of nature suggests "an occult relation between man and the vegetable. I am not alone and unacknowledged," he writes. "They nod to me, and I to them" (11). Though neither Honoré nor Emerson are pursuing sex, both are, with their determined aimlessness and radical openness to alterity, cruising. The "voluptuous commerce" in which they are engaged is reciprocal, but without the expectation of material exchange. As the encounter between the duke and usher suggests, monetary exchange, while common, was often voluntary, and conventions of who should service whom were flexible. Unlike the social economy of the aristocracy or the bourgeoisie, the economy of pleasure is not founded in give-and-take, but in, to repeat Sedgwick's comments on the génie, "plenitude [and] gifts without exchange" (Sedgwick 19). Of course, Emerson's affection for the vegetable is shadowed by his apparently suppressed power to consume it. This subtext once again encourages us to attend to the possibility of cruisers instrumentalizing one another on the basis of power differentials, e.g. Honoré's privileged social status. In doing so, however, we run the risk of collapsing social difference with more general 
otherness. In encounters driven by pleasure rather than, or in addition to, profit, difference is more likely to determine institutional response, such as who is arrested or more aggressively punished by the criminal justice system. On the other hand, otherness is usually the very source of cruising's singular jouissance, and by extension its ethics.

Given that the génie is a manifestation of social force, it seem only natural that Proust cites the divinity-field in describing cruising. Like a light in the forest that leads wanderers into the fairy-world, the génie of cruising brings the queer threshold to us. On the other side is the transcendance Bersani describes, a liberation from identity (both our own and others'), a pleasure in socialization that demands no prior affinities, and a generosity that entails no charity or self-sacrifice. Similar non-teleological gestures and crossings mark the Recherche from its beginning; after all, the novel opens with an episode of transmigration that leaves the narrator with "seulement...le sentiment de l'existence comme il peut frémir au fond d'un animal" [only the most rudimentary sense of identity, such as may lurk and flicker in the depths of an animal's consciousness] (Proust 1:5; 1:4). Of course, such a shock is only momentary, and we soon regain our senses. Yet if, as I have argued, cruising offers a glimpse of how the social in Proust may be redeemed, and moreover that it is enabled by the same forces that animate nearly every other aspect of the Proustian world, then it is surely as integral to the novel's structure as any of its more towering moments. In brief, I agree with Lawrence Schehr that the Recherche cannot be understood outside the context of homosexuality, but add that homosexuality in the Recherche cannot be understood outside the context of cruising. 


\section{THE DisCREet CHARM OF THE ARISTOCRACY: SEX, ClASS, AND FETISHISM}

The episode of the Duc de Châtellrault presents two very different visions of the social in quick succession. While the anonymity experiences while cruising is undoubtedly liberatory for the duke, the drama at the soirée hinges on the anxiety of being recognized, identified, and named. The narrator himself fears being announced so greatly that he compares the usher to an executioner. Yet in Proust, where things that end always persist or recur, every executioner is also a psychopomp. If we look at the threat posed by the usher as transformative rather than mortal, we can illuminate the relationship between the duke and usher as members of the same sexual public on one day, and of disparate social classes the next. In addition, further attention to this scene can help limn the possibilities of queer desire as a transgressive and perhaps even even utopian gesture.

I outline above kinds of free socialization and misalliances that cruising engenders, yet the encounter in question recalls another carnival trope: the world turned upside-down. Edward Hughes has argued that the "migration and reconstitution of identity" is crucial to understanding the Recherche (672), and the duke and usher clearly undergo such a metamorphosis: while they return to their respective class stations after parting ways, their second encounter entails a carnivalesque inversion of power, with the usher changed into an executioner and the duke, his victim. This shift is consistent with Proust's habit, as J.E. Rivers notes, of explaining various phenomena by way of “inversion," one of the most frequently used words in the novel. Not only do the narrator's observations frequently 
hinge on the inversion of his initial impressions, but such surprising and often revelatory reversals are built into the structure of the Recherche on the grandest scale (Rivers 215-221).

Here, however, the inversion is followed by a reversion once it has been shown that the threshold poses no real threat. As at the end of a carnival, where the sham king is dethroned and the hierarchy is restored, once the duke crosses the queer threshold his identity and status reassert themselves, along with the normative boundary of public and private space exemplified by the soirée. What we are left with is merely a suggestion of change, a gesture towards a world that neither the duke, the usher, nor Proust himself seem prepared to imagine, one in which power relations are altered completely rather than simply inverted. If there is a utopian impulse in this episode (I argue that there is, to a degree), it imagines nothing more revolutionary than a world in which "les radicaux, les juifs [seront] reçus au Jockey" [radicals and Jews might become members of the Jockey]; which is to say, there will always be a Jockey club (Proust 4:537; 6:394).

The shift in power between the duke and usher also bears cultural echoes of the French Revolution and of the ambivalent and often threatening role of domestic servants in French literature, from Racine's EEnone to Proust's own Françoise. As Morel reminds Charlus at one point, there was a time "où mes ancêtres firent couper le cou aux vôtres" (3:449; 4:628). Yet in the latter's "Heraclitean world, in which reality is constantly in flux and 'the way up' is also 'the way down'” (Rivers 220-221), their class dynamics both challenge and reinforce a hierarchy that is, all the while, being ineluctably refashioned by an ascendant bourgeoisie. Unlike Morel, the usher articulates no actual threat to the duke that would not rebound on himself. Furthermore, he is menacing to the narrator precisely because he is an agent of the aristocracy, a milieu in which the narrator worries he has not 
been welcomed, not because he embodies the threat of a popular uprising. In fact, the Recherche, while adroitly documenting the class struggle between the aristocracy and bourgeoisie, largely fails to account for the increasingly militant working class who would soon become the primary enemy of the bourgeoisie (Sprinker 183). For Proust, the most significant instance of class transgression in this episode may be his narrator's own entry into the Guermantes' soirée, not the rendez-vous between noble and servant.

We have already noted several ways in which cruising differs from other kinds of socialization. These should not, however, be flung into binary opposition. While cruising is, as Barthes describes it, "withdrawn from all repetition" (231), all of these "first times" are also beginnings, and the fleeting encounter can quickly and easily become any number of quite different relationships (even sex itself is not, strictly speaking, cruising). Thus, while cruising is a highly conventional kind of socialization, open to all but demanding a specific kind of literacy, it is just as much a threshold giving onto virtually infinite social possibilities. Thus we cannot say that the usher breaks convention in asking for the duke's name on the avenue Gabriel, nor that the duke does in refusing to offer it. Moreover, while the usher may not be entirely disinterested in his relation to the duke, he certainly makes no attempt to blackmail him on the basis of their hookup as many young, working-class Parisian men did (Peniston 28). He seems to have no intention of either prolonging their relationship nor exploiting the encounter. Why, then, does he attach such importance to the duke's name? Where does Proust's supposedly straight narrator fit into this queer drama? What does the emotional charge of this scene have to do with the microcosmic social hierarchy it presents us? 
We can answer the first question by partially answering the second. As Michael Lucey observes, the narrator shares with Chatell rault his fear of being named, while he and the usher share an outsized adoration for members of the aristocracy $(246-247)$. In the narrator, this manifests as a fear that being announced will embarrass the Princesse de Guermantes, since his announcement will alert the other guests that she has invited someone of his (lower) social standing to her soirée. The doorman, on the other hand, displays an "emotional tenderness" as he announces the duke, ornamenting and exalting the latter's "appellation that was too modest" (Proust 3:37; 4:49-50). Both the usher and bourgeois narrator are prioritizing the needs of their aristocratic objects of affection: of the princess to maintain her reputation and the exclusivity of her salon, and of the duke to hide his sexual desires and assert his belonging in the princess' milieu.

For Lucey, such concerns arise from a "vaguely mystified relation to...talismanic figure[s] from an elevated social position" (247, emphasis mine). While he does not push his analysis much further on this point, Lucey's remark nevertheless suggests that Proust's queer pantheism may have further relevance to the passage in question. Proust may not have been exaggerating, but instead evoking the kind of performative utterances common to religious rituals (prayers, invocations, etc.), when he writes that the usher announces the narrator "avec une force capable d'ébranler la voûte de l'hôtel"[with a force capable of bringing down the roof] (Proust 3:37; 4:50). If the usher's desire to know the duke's name is bound up with one of the novel's most pervasive themes, then perhaps the narrator's role in this scene is, at least in part, to suggest various linkages between the usher/Châtellrault episode and other unifying threads that run through the Recherche. In situating his 
narrator as such, Proust is able to displace queer themes onto secondary characters while continuing to weave them into the very fabric of the novel.

These linkages bring queerness, even in passages as fleeting as the one in question, into conversation with Proustian themes that are, on their faces, sexually neutral. For example, we can see echoes of the madeleine moment in the Châtellrault episode. In particular, the themes of (mis)recognition and the performative, almost magical, power of naming crop up prominently in the following metaphor for memory from Du côté de chez Swann:

Je trouve très raisonnable la croyance celtique que les âmes de ceux que nous avons perdus sont captives dans quelque être inférieur, dans une bête, un végétal, une chose inanimée, perdues en effet pour nous jusqu'au jour, qui pour beaucoup ne vient jamais, où nous nous trouvons passer près de l'arbre, entrer en possession de l'objet qui est leur prison. Alors elles tressaillent, nous appellent, et sitôt que nous les avons reconnues, l'enchantement est brisé. Délivrées par nous, elles ont vaincu la mort et reviennent vivre avec nous. (1:43־44)

[I feel that there is much to be said for the Celtic belief that the souls of those whom we have lost are held captive in some inferior being, in an animal, in a plant, in some inanimate object, and thus effectively lost to us until the day (which to many never comes) when we happen to pass by the tree or to obtain possession of the object which forms their prison. They start to tremble, they call us by our name, and as soon 
as we have recognized them the spell is broken. Delivered by us, they have overcome death and return to share our life.] (1:59)

Proust recycles this metaphor in A l'ombre de jeunes filles en fleurs, when describing his remorse at donating his family's furniture to a brothel: "Je ne retournai plus chez l'entremetteuse, car [les meubles] me semblaient vivre et me supplier, comme ces objets en apparence inanimés d'un conte persan, dans lesquels sont enfermées des âmes qui subissent un martyre et implorent leur délivrance" [I returned no more to visit their new mistress, for they seemed to me to be alive and to be appealing to me, like those apparently inanimate objects in a Persian fairy-tale, in which imprisoned human souls are undergoing martyrdom and pleading for deliverance $(1: 568 ; 2: 208)$.] If these references to pre-Christian belief systems highlight the narrator's habit of assigning talismanic value to objects and people, the Chatelllrault episode marks another return of this theme, now in a queer context.

Is the duke calling out to be recognized? Does he need to be delivered, and from what? Or perhaps it is the usher who, by calling the duke, seeks to revive the inexpressible trace of their chance encounter? In Proust, the names of people can, like those of places, "recall or suggest phantoms...that still move about, concealed in gestures and in bodies in motion" (de Certeau 105). In this sense, this brief digression in the early pages of Sodome et Gomorrhe is hardly different from the madeleine episode or the suite of revelatory moments in Le Temps retrouvé: it seeks to capture the ways in which that which has passed — people, places, objects, sensations, etc. - can persist in the imprint they leave on us, as well as the imprint, unreadable to anyone else, that we discover in what remains. If Proust so often uses magic or mysticism to metaphorize the relation between self and memory, this is because they "represent the enchantment that the human mind casts over the world—an enchantment that 
human reason does not fully comprehend, but that provides profound indices to the workings of the inner self" ("Marcel Proust" 106). There is no reason that the lingering trace of a hookup in a park should be any less significant in this respect than that of a cookie dipped in tea.

Sexuality compounds the inexpressible nature of this imprint in two major ways. First, it is tied up with the general difficulty of expressing queer desire in the Recherche. What this passage decisively shares with Proust's description of the friends at the brothel door is the way in which homosexuality is displaced along a chain of potential "narrators": from the writer himself, to his narrative voice, to the usher whose interiority the narrator is somehow privy to (for more on this, see Lucey 241-249), and finally to Châtellerault. Perhaps even more importantly, however, this naming gives the usher some kind of language with which he can stabilize the fleeting, evanescent ecstasy of their encounter. Of course, the name itself is unsatisfactory to preserve his pleasure; as Proust writes decades earlier in the short story "Un dîner en ville," the words Honoré lets out during his ecstatic stroll "étaient une bien banale traduction de pareilles visions qui...n'étaient peut-être pas exprimables" [were an altogether banal translation of similar visions which...were perhaps not amenable to expression] (103; 107). The spatial practices embodied in Honoré's urban wandering or the usher's cruising entail varieties of knowledge that can be mutually understood, but hardly communicated. Such experiences are reduced to deictic gestures: "here is where I first noticed the duc de Châtellrault, then we went over there," and so on. In all of these examples, sexual desire and even more general feelings of wellbeing can only be pointed at in an interminable movement towards (see Muñoz 19-32). This gesture, like cruising itself, is never completed but rather exceeds beginnings or 
ends (Ricco par. 13), remaining poised, like the urban walker rounding a corner, for surprising encounters.

This analysis can further speak to the utopian impulse in this episode. Of course, Proust himself is not a utopian writer: he conceives of an egalitarian society only in terms of upward mobility (certainly the result of his bourgeois upbringing), portrays a potentially utopian class who have nothing but free time in which to cultivate themselves and instead flounder in boredom and "vice," and is almost completely blind to the economic forces facilitating such an existence (Sprinker 181-184). Insofar as any utopian project is ever fully developed, Proust's amounts to little more than a glance. However, the "emotional tenderness" inflecting the duke and usher's sexually and economically transgressive relation may itself be just such a glance. While in no way does Proust suggest a classless society in the vein of Marx, he is documenting one in which cross-class relations have the potential to be marked, not by the threat of violence, but by a kind of pleasant intimacy.

This sort of intimacy, as Samuel Delany argues in the context of zoth century New York, does not necessarily reduce antagonism between the classes, but can stabilize cross-class relationships on a personal level (114). Given the immense, if uneven, changes to France's economy and social structure during the Third Republic, reducing interpersonal antagonism on the basis of class was desirable. For his narrator, this could mean easier access to society's upper echelons, his primary motive until the middle of the novel sees his efforts redirected towards Albertine. But more generally, it accords with Proust's project of portraying a world that is both fractured and discontinuous, while also, in Neoplatonic fashion, unified and organic. Sex and intimacy between the classes is, in this sense, part and parcel with Proust's portrayal of a disintegrating aristocracy being faced with its contingency 
and porosity. Once again, we see the anxiety of inside/outside defining Proust's characters' relation to self, space, and society.

It is important to note the slippage between the "pleasant" and pleasure, in the same way that we have shown Honoré's non-sexual stroll in "Un dîner en ville" to be shot through with erotic possibility. One does not necessarily lead to the other, but the effects can be similar. For example, at the same soirée at which Châtellrault is present, Madame d'Arpajon, one of the duc de Guermantes' mistresses, is soaked by water blown from a fountain to the delight of the other guests. (This episode is significant in relation to Proust's social vision in more ways than will be discussed here; for more on this, see Bidou-Zachariasen, as well as Sedgwick 1-3.) One of the results is that Charlus, who had been cold to the narrator moments before, touches his shoulder and says laughing: "Allons, ne vous fâchez pas...vous savez que je vous aime bien. [...] Avez-vous été voir le jet d'eau?” [Come, now, don't be cross...you know I'm fond of you. Have you been to look at the fountain?] $(3: 58 ; 4: 78-79)$. The scene caused by the fountain offers both Charlus and the narrator a comic touchstone by which their interpersonal tension can be spontaneously smoothed over. While this tension is not necessarily class-based, the baron's condescending and even disdainful attitude towards the bourgeois narrator suggests that their relationship is inflected with class antagonism and marked by the threat, to the baron, of the aristocracy's bourgeois infiltration. Here, the pleasantness of comedy brings their tension into a temporary equilibrium, without going nearly so far as to resolve it.

If this episode shows how the pleasant can affect interclass relations, the usher's announcement of Châtellrault shows how pleasure can do the same. Towards the end of the passage, the narrator observes the "orgueil" that the usher feels when he glimpses the duke. This "burst of 
pride" carries, in French, a somewhat more negative connotation that the alternative, "fierte'". While this connotation might lead one to attribute the usher's pride to the unexpected power he now holds over the duke, this does not seem to be the case. Instead, his announcement augments the duke's pedigree, reinforcing the latter's belonging in the aristocratic circle. His pride derives not from a shift in power, but from the value he attaches to the duke's status. The announcement of the duke reinforces this; by enhancing the latter's title, the usher emphasizes their social difference in order to maximize the fetishistic significance of their encounter. In other words, his particular pleasure here is entirely dependent on the existence of a class hierarchy.

On the other hand, the usher's "professional energy" is tempered by an "emotional tenderness." If the announcement is a performative utterance that permits the duke to cross the threshold, the tenderness with which it is inflected softens the very contours of this barrier. This tenderness is both stabilizing and destabilizing; while it sentimentalizes the normative relationship between the classes, it also poses a challenge to their parameters. I have already argued that it is the narrator, not the usher, who is the primary class transgressor in this passage. In the same spirit, I find its most compelling source of tension to be not the usher's anticipation nor the duke's anxiety, but the ambivalent relation between class and intimacy to which the act of announcement calls attention. It would be too facile to posit their encounter as a revolutionary transgression "capable of bringing down the roof." It does not point to a latent radicalism in Proust as a social critic. Instead, it is exactly this kind of frustratingly incomplete gesture that characterizes the novelist's embryonic utopian vision. While sex in this passage does draw attention to the ways in which social hierarchies exist as 
both open and closed systems, Proust does not attribute to it the power to upend them. Sexuality knows no class boundaries, but this does not mean it nullifies them.

However, if we read this passage and thematically similar ones in the light of Proust's notorious pessimism regarding love and society, it is impossible to ignore the ways in which they brush the narrator's more general conclusions against the grain, exposing tantalizing possibilities underneath. For example, nearly all queer intimacy in the Recherche crosses class boundaries. Significantly, the working classes rarely figure in the novel outside of a sexual context. Aside from the anachronistic Françoise, they appear as milkmaids about whom the narrator fantasizes on the train to Balbec, as employees at Jupien's brothel, or as actresses such as Lea the lesbian crossdresser or Rachel the prostitute. Despite the narrator's overwhelming sexual paranoia, he seems to appreciate the non-normative potential of these libidinous, transient, and transgressive kinds of relationships. Reflecting in La Prisonnière on the "scene of masochism" in which Mlle. Vinteuil and her "amie" profane a photograph of M. Vinteuil, he eventually concludes that "de relations qui ne sont pas consacrées par les lois découlent des liens de parenté aussi multiples, aussi complexes, plus solides seulement, que ceux qui naissent du mariage" [Relations which are not sanctioned by the law establish bonds of kinship as manifold, as complex, and even more solid, than those which spring from marriage] $(3: 766 ; 5: 348)$. If readers are already familiar with the narrator's gloomy view of marriage, it is still shocking to read such an affirmation of non-normative, even queer, relations — above all when they concern female homosexuality, the horrifying mystery of which plagues the narrator for several hundred pages. In a similar vein, Proust's sympathetic portrait of the usher suggests a permissive, 
nearly sentimental attitude towards sex and non-normative sexuality that is all but lost in the tragic conception of love that dominates the text.

Overall, however, Proust resists any such romanticization. Consider Charlus, who seeks out sexual partners almost exclusively from the lower echelons of society, such as Jupien, Morel, the brothel employees in Le Temps retrouvé, and the narrator himself, who the baron cruises in A l'ombre de jeune filles en fleurs. Once again, what Lawrence Schehr refers to as the baron's "democratic" sexual taste nonetheless entails the fetishization of class and the exercise, and sometimes symbolic exchange, of power (French Gay Modernism 46). Speaking with Jupien, he evokes his lineage—including three popes and a cardinal, from whom he inherits the right to wear a red cape - in order to underline the "prodigieux personnage qui je suis" [prodigious personnage that $\mathrm{I}$ am] and the "microscopique vibration qu'il [le narrateur] figure" [microscopic animalcule that he is in comparison] [(3:14; 4:16). In contrast, Jupien reassures Charlus at his brothel that he has procured for him "un des plus dangereux apaches de Belleville" [one of the most dangerous thugs in Belleville] to adequately abuse and degrade him, all while the brothel employees complain about the effort required to haul around the accountements of BDSM (4:393-396; 6:180-184). Furthermore, for much of the novel he attempts to shape Morel, his working class lover, into a proper protegé, suggesting that class difference is hardly tolerable in a long-term, semi-public relationship.

The example of the duke and usher varies little from this schema in which eroticism between the classes is heightened by fetishistic associations. This conclusion does beg the question of whether or not their class standings were legible to one another in the initial encounter, or only at the soirée. Was this fetishization a component of the eroticism of their meeting, or did it only retroactively 
accentuate it? While such questions have ramifications for the reading I present here, they are unanswerable in terms of what the text itself supplies. Suffice to say that the class dynamic between the duke and usher remains bound up with inversions, rather than transformations, of convention: like the baron finding pleasure in being whipped by a hoodlum, Châtellerault takes pleasure in servicing an older man from a lower station, who himself feels some self-importance upon learning of the duke's aristocratic pedigree. All of these examples trouble class lines, and bear witness to the loss of balance felt by those attentive to the kaleidoscopic reorientation of French society. Yet, as for the pieces of glass in a kaleidoscope, the possibility of social movement in Proust is circumscribed in two dimensions: up or down, in or out.

\section{CONCLUSION}

In regards to class, Proust himself was on a historical threshold. As a participant in the penetration of the aristocracy by the bourgeoisie, he adroitly documents and interprets the convectional shift in power among the French upper classes. Nevertheless, he seems unable to divine the growing influence of the working class, largely ignoring production in order to focus on a class defined by consumption and a feudalism that no longer had any concrete reality. In his quickness to gloss over the economic underpinnings of the society he portrays, he relegates the majority of the Parisian population to the margins of the text. However, these margins serve as fecund spaces in which the impulses suppressed elsewhere in the novel find expression. Inevitably exceeding their 
margins, these impulses subtly challenge the orderly, conservative Third Republic society that the narrator appears simultaneously critical of and invested in.

If Proust displays an ambivalent and somewhat myopic view of class relations, the moments of transcendent jouissance between elites and the dark matter of French society serve as points of rupture that complicate, without entirely rewriting, his overarching social critiques. Yet such points of rupture are just as much ones of rapture: the ecstatic urban strolls, sexually democratic attitudes, and collective pleasures of Proust's characters suggest, as Walter Benjamin describes it in "The Image of Proust", an eternity that is neither platonic nor utopian but nonetheless "rapturous" (210). My redemptive reading of cruising's role in Proust seeks to recover this rapture, though not to isolate it. Instead, I attempt to show how carefully it is woven into the novel's thematic web, how inextricable queerness and cruising are from the universe of the Recherche. Proust may not theorize cruising in the way that he does memory, but that does not mean that the illicit matter of his novel is any less important than its explicit preoccupations. Queer sexual desire is in constant conversation with the rest of the Recherche; the novel, like queer desire itself, operates on a principle of resonance. Any study of Proustian sexuality must therefore account for time, memory, place, social relations, language, and so on, while these latter themes should not be divorced from the libidinous strain running through the text.

The Recherche is, among other things, Proust's Parisian "carte de tendre," an imprint of once-embodied pleasures and pains that were inscribed invisibly upon the city long before they were inscribed in the author's copious notebooks. The inexpressible traces of these affects animate the city, find it teeming with guardian spirits, with génies. These beings embody the author's sense of magic as 
"the enchantment that the human mind casts over the world" ("Marcel Proust" 106), the ineffable affinity between site and self that tells us "I felt good here." Such resonance between inside and outside is what allows the narrator to imagine that, in the midst of his deathbed anguish, the barometric génie inside him will heedlessly celebrate the day's fine weather (Proust 3:522; 5:5-6). In brief, Proustian magic circumvents the endless mediating factors that range themselves between us and the world.

Nearly a century after the publication of Sodome et Gomorrhe, intimacy has indeed become mediated to greater and greater degree. In the US, one might think of the preponderance of gay hookup apps and websites, as well as the ways in which the paranoia of contagion has given way to the era of safe sex with condoms and, now, PrEP. Moreover, as public sex has declined and our cities have become more and more surveilled, most anonymous sex now occurs within demarcated play spaces like bathhouses, sex clubs, and sometimes hotel rooms or private residences. These changes are not universally negative - for example, I would be remiss if I did not celebrate the countless benefits of Truvada, even if I admit discomfort with the idea of Gilead Sciences mediating bareback sexual encounters and with the drug's cost for the uninsured. However, many of these shifts indicate the cordoning-off of sexuality, its relegation to the private sphere that is but one expression of the triumph of bourgeois normativity. Situating sexuality on one side of the public/private divide reduces the socio-political concerns of queer people, which include broad issues like poverty, racism, health care, etc., to individual and often bourgeois pet projects like gay marriage or military service.

One effect of this is that what in the US are referred to as "social issues," in contrast with "economic issues," are construed as moral decisions that are divorced from the economic conditions 
that breed and shape them. The privatization of sexuality also casts the home as the center of civic responsibility, diminishing the political power of urban citizens by shifting it from the collective to the individual or, perhaps the heterosexual family unit. If sexuality is abstracted from questions of economics and politics, then it is consequently cast as a haven from these corrupting and divisive forces, a haven that most often takes the shape of coupling, marriage, and procreation. However, unreflective acquiescence to these norms ultimately collapses the economic and political ideologies of the United States with the purity and sanctity of the home, allowing for the unwitting proliferation of heteronormativity as an ideology itself.

Finally, the exploding market around queer identity subsumes the informal and open-ended economy of pleasure under the recklessly consumptive model of post-industrial capitalism. This institutionalization of sexual expression is predicated on an exploitative colonial model much more damaging than the sexual colonialism of inter-class cruising. If the propagation of queer identity markers (paradoxical as that may sound) gives those on the consuming end of production a feeling of liberation, this is itself predicated on the abuse of the producers, many of whom are of course queer themselves. In short, the freedom and acceptance of queer consumers exists in inverse proportion with the oppression of queer producers, with a great deal happening in between.

I do not propose cruising as a panacea to this crisis. Much less do I believe that reading Proust will spark a sexual revolution. Not only is Proust, as I argue, decidedly not a utopian writer, but the utopian potential of cruising itself is fraught, since its opposition to pragmatic politics is both its most attractive and most frustrating feature. Yet it is not necessarily the practice of cruising, but the ethos and ethic than animates it, that is both the source of its emancipatory power. The asymptotic 
relationship between utopia and the now, always approaching but never touching, is just another model with which to rethink intimacy and otherness. The Recherche suggests (I do not say "proposes") a way of embodying intimacy that, by dint of its vital animacy, is charged with the potential to reimagine the relationship between the individual and the urban mass. In other words, it recasts intimacy in a way that appears novel, but is in fact quite old, even timeless.

Proust's novel depicts a living city, reverberating with small moments of pleasure, traversed by benevolent spirits that draw us unknowingly together. This is a city characterized by surprise, surprise which is the "mark of reality, insofar as what is real...has to exceed the will of the subject," but which also comprises "the mystical orientation that allows Proust to cherish this reality" (Sedgwick 34). There is little in Proust as powerful as his injunction to cherish, even while reminding us that we will never cherish fully. But overall, Proust presents us with a pleasant city, one in which anxious, often selfish intimacy of the bedroom gives way to the "voluptuous commerce" of the urban stroll. This intimacy, like all queer desire in the Recherche, is inexpressible in language —one possible explanation for why Proust's utopian imagination seems to fall short. Yet the novel does show us this impersonal, anonymous intimacy expressed in a range of embodied social and spatial practices. Furthermore, it furnishes the material to interpret these practices, if one is willing to look at it from far enough away to see how its different components converse with one another. Or, alternatively, one can simply step out onto the street and cruise through the crowd, come what may. 


\section{WORKS CITED}

Bakhtin, Mikhail. Problems of Dostoevsky's Poetics. Translated by Caryl Emerson, U of Minnesota P, 1984.

Barbedette, Gilles and Michel Carassou. Paris Gay 1925. Presses de la Renaissance, 1981.

Barthes, Roland. The Grain of the Voice: Interviews 1962-1980. Translated by Linda Coverdale, Hill \& Wang, 1985 .

Benjamin, Walter. Illuminations: Essays and Reflections. Translated by Henry Zohn, Harcourt Brace, 2007.

Berlant, Lauren, and Michael Warner. "Sex in Public." Critical Inquiry, vol. 24, no. 2, 1998, pp. $547-566$.

Bersani, Leo. "Sociability and Cruising." Sameness, special issue of Umbr(a), no. 1, 2002, pp. 9-23.

Bidou-Zachariasen, Catherine. "Le « jet d'eau d'Hubert Robert » ou Proust analyste de la mobilité sociale." Ethnologie française, vol. 20, no. 1, Jan-Mar 1990, pp. 34־41.

Carter, William C. Proust In Love. Yale UP, 2006.

de Certeau, Michel. The Practice of Everyday Life. Translated by Steven Rendall, U of California P, 1984.

Dean, Tim. Unlimited Intimacy: Reflections on the Subculture of Barebacking. U of Chicago P, 2009.

Delany, Samuel R. Times Square Red, Times Square Blue. New York UP, 1999.

Deleuze, Gilles. Proust et les signes. Quadrige, 1998.

Emerson, Ralph Waldo. Essays and Lectures. Library of America, 1983.

Ensor, Sarah. "Queer Fallout: Samuel Delany and the Ecology of Cruising." Environmental Humanities, vol. 9, no. 1, 2017, pp. 149-166.

Finn, Michael R. "Proust et le roman du neurasthénique." Revue d'Histoire littéraire de la France, vol. 69, no. 2, 1996, pp. 266-289.

Gowrie, Lord. “Obituary: Francis Bacon.” The Guardian, 29 April, 1992.

Hardy, Thomas. The Well Beloved. Harper \& Brothers, 1897.

Hayes, Jarrod. "Proust in the Tearoom." PMLA, vol. 110, no. 5, 1995, pp. 992-1005.

Hughes, Edward. "Proustian Metamorphosis: The Art of Distortion in À la recherche du temps perdu." Modern Language Review, vol. 94, no. 3, 1999, pp. 660-672.

Lewis, Pericles. "Citizens of the Plain: Proust and the discourse of national will." Modernism Nationalism, and the Novel. Cambridge UP, 2000.

.... "Marcel Proust and the elementary forms of religious experience." Religious Experience and the Modernist Novel. Cambridge UP, 2010.

Lucey, Michael. Never Say I: Sexuality and the First Person In Collette, Gide, and Proust. Duke UP, 2006. 
Muñoz, José Esteban. Cruising Utopia: The Then and There of Queer Futurity. New York UP, 2009.

Peniston, William A. Pederasts and Others: Urban Culture and Sexual Identity in Nineteenth Century Paris. Harrington Park, 2004.

Porzak, Simon. "Inverts and Invertebrates: Darwin, Proust, and Nature's Queer Heterosexulity." Diacritics: A Review of Contemporary Criticism, vol. 41, no. 4, 2013, pp. 6-35.

Proust, Marcel. À la recherche du temps perdu. Gallimard, 1987-89. 4 vols.

-.-.. In Search of Lost Time. Translated by C.K. Scott Moncrieff and Terence Kilmartin, revised by D.J. Enright, Modern Library, 2003.

-..-. Pleasures and Days. Translated by Andrew Brown, Hesperus, 2004.

...-. “Un Dîner en ville." Jean Santeuil, précédé de Les Plaisirs et les jours, Gallimard, 1971, pp. 97-103.

Ricco, John Paul. "The Art of the Consummate Cruise and the Essential Risk of the Common, Part II: Cruising as Aesthetic Intuition of the Common." Feedback, www.openhumanitiespress.org/feedback/sexualities/the-consummate-cruise-2/. Accessed 8 October 2018.

Rivers, J.E. Proust and the Art of Love. Columbia UP, 1980.

Ross, Andrew. Urban Desires: Practicing Pleasure In the "City of Light," 1848-1900. Dissertation, U of Michigan P, 2011.

Schehr, Lawrence. The Shock of Men: Homosexual Hermeneutics in French Writing. Stanford UP, 1995 .

-..-. French Gay Modernism. U of Illinois P, 2004.

Sedgwick, Eve Kosofsky. The Weather in Proust. Duke UP, 2011.

Sprinker, Michael. History and Ideology In Proust: À la recherche du temps perdu and the French Third Republic. Cambridge UP, 1994.

Stanley, Kate. “Through Emerson's Eye: The Practice of Perception in Proust." American Literary History, vol. 28, no. 3, 2016, pp. 455-483.

Weeks, Jeffrey. Against Nature: Essays on History, Sexuality, and Identity. Rivers, 1991.

Wilson, Michael L. "Drames d'amour des pédérastes: Male Same-Sex Sexuality in Belle Epoque Print Culture." Journal of Homosexuality, vol. 41, no. 3-4, 2002, pp. 189-200.

Wittig, Monique. "The Trojan Horse." "The Straight Mind" and Other Essays. Beacon, 1992, pp. 68-75. 